\title{
Caracterização Demográfica, Curso Clínico e Fatores de Risco para Mortalidade em Doentes Hospitalizados com COVID-19: Experiência de um Hospital Terciário Português na Primeira Vaga da Pandemia Demographic Characterization, Clinical Course and Risk Factors for Mortality of Adult Inpatients with COVID-19: A Single-Centre Experience from the First Outbreak in Portugal
}

Pedro Antunes Meireles*1,2 (https://orcid.org/0000-0002-3356-1969), Pedro Gaspar ${ }^{\star 1,3}$ (https://orcid.org/0000-00026965-3435), Inês Parreira1 (https://orcid.org/0000-0003-2017-2697), Ana Mafalda Abrantes ${ }^{1,3}$ (https://orcid.org/00000002-1295-9679), Virgílio Dias Silva ${ }^{1,4}$ (https://orcid.org/0000-0003-1746-7742), Filipe Bessa ${ }^{1,3}$ (https://orcid.org/00000002-6006-6621), António Pais de Lacerda ${ }^{1,3}$ (https://orcid.org/0000-0002-3001-8848), Catarina Mota ${ }^{1,3,5}$ (https://orcid. org/0000-0001-8835-6527)

\section{Resumo:}

Introdução: As informações relativas às características clínicas e demográficas dos doentes portugueses hospitalizados com COVID-19 são limitadas.

Material e Métodos: Estudo ambispetivo dos doentes internados com COVID-19 num hospital terciário português entre março e agosto de 2020. Foram excluídos os doentes assintomáticos, mulheres grávidas e os internados por causas sociais.

Resultados: Dos 432 doentes internados, foram incluídos 279. A idade mediana foi de 69 anos, $57 \%$ do sexo masculino. As comorbilidades mais frequentes foram a hipertensão arterial $(66,3 \%)$, dislipidémia $(33,3 \%)$, diabetes $(27,1 \%)$ e doença cardiovascular (DCV) (26,5\%). A sintomatologia mais frequente à admissão foi febre $(74,4 \%)$, tosse $(67,0 \%)$ e dispneia (59,9\%). As alterações laboratoriais mais frequentes foram níveis elevados de ferritina (86,3\%), proteína c-reativa $(74,8 \%)$ e d-dímeros (73,9\%). A taxa de mortalidade foi 17,3\%, 32,3\% dos doentes desenvolveram síndrome de dificuldade respiratória aguda, 31,9\% foram admitidos numa unidade de cuidados intensivos e $20,8 \%$ foram ventilados mecanicamente. Na análise multivariável, a idade (OR 1,04, 95\% Cl 1,01-1,09, $p=0,023)$, DCV (OR 2,68, 95\% Cl 1,21-5,93, $p=0,015)$ e linfopenia $<0,5 \times 109 / \mathrm{L}$ (OR 6,61, 95\% Cl 2,23-19,62, $p=0,001)$ identificaram-se como os principais fatores de risco de mortalidade intra-hospitalar.

Discussão: Os nossos dados demográficos e desfechos

${ }^{1}$ Serviço de Medicina 2, Hospital de Santa Maria, Centro Hospitalar Universitário Lisboa Norte, Portugal

${ }^{2}$ Serviço de Oncologia Médica, Instituto Português de Oncologia de Lisboa Francisco Gentil, Portugal

${ }^{3}$ Faculdade de Medicina, Universidade de Lisboa, Portugal

${ }^{4}$ Serviço de Medicina Intensiva, Hospital de Santa Maria, Centro Hospitalar Universitário Lisboa Norte, Portugal;

Instituto de Medicina Molecular, João Lobo Antunes, Universidade

de Lisboa, Portugal.

*Primeira co-autoria

DOI:10.24950/O/30/21/2/2021 clínicos equiparam-se aos estudos publicados até à data. Em comparação com os estudos em populações europeias, relatamos uma menor taxa de mortalidade intra-hospitalar, o que poderá refletir um melhor controlo da primeira vaga da pandemia no nosso país.

Conclusão: Este estudo fornece informação acerca das características clínicas dos doentes com COVID-19 hospitalizados em Portugal.

Palavras-chave: COVID-19; Demografia; Factores de Risco; Mortalidade; Portugal; SARS-CoV-2.

\section{Abstract:}

Introduction: Clinical characteristics of Portuguese inpatients with coronavirus disease 2019 (COVID-19) are scarce. We aim to describe the demographic characteristics, clinical course and outcomes of hospitalized patients with COVID-19 and to analyze risk factors for in-hospital mortality.

Material and Methods: Ambispective cohort study of adult COVID-19 patients admitted to a Portuguese tertiary hospital between March and August 2020. Asymptomatic, pregnant and all patients admitted due to social reasons were excluded.

Results: Of the 432 admitted patients, 279 individuals were included. The median age was 69 years and 57\% were male. The most common comorbidities were high blood pressure (66.3\%), dyslipidemia (33.3\%), diabetes (27.1\%) and cardiovascular disease (CVD) (26.5\%). The most common symptoms included fever (74.4\%), cough (67.0\%) and dyspnea (59.9\%). Ferritin, C-reactive protein and D-dimer levels were elevated in $86.3 \%, 74.8 \%$ and $73.9 \%$ of patients, respectively. Mortality rate was $17.3 \%$. $32.3 \%$ of the patients developed acute respiratory distress syndrome, $31.9 \%$ were admitted to intensive care unit and $20.8 \%$ were ventilated. In multivariable analysis, age (OR 1.04, 95\% Cl 1.01-1.09, $p=0.023$ ), CVD (OR 2.68, 95\% Cl 1.21-5.93, $p=0.015$ ) and lymphocyte count $<0.5 \times 109 / L$ (OR 6.61, 95\% Cl 2.23-19.62, $p=0.001$ ) were risk 
factors for in-hospital mortality.

Discussion: Our demographics, clinical and severity outcomes are in-line with international reports. Compared to other European countries, our less expressive in-hospital mortality rate might reflect a modestly controlled first outbreak in our country.

Conclusion: This single-center study provides data on the clinical characteristics and outcomes of hospitalized patients with COVID-19 in Portugal.

Keywords: COVID-19; Demography; Mortality; Portugal; Risk Factors; SARS-CoV-2.

\section{Introduction}

Portugal's first case of coronavirus disease 2019 (COVID19) was notified on March $2^{\text {nd }}, 2020$. Since then, over 800000 cases were diagnosed and 16000 deaths were reported.

Knowledge about the clinical characteristics and outcomes of COVID-19 patients is persistently increasing due to a growing body of evidence from international reports, mainly from China ${ }^{1,2}$ and United States of America (USA), ${ }^{3}$ but also from some European centres. ${ }^{4-6}$ Demographic, environmental, cultural characteristics and comorbidities prevalence likely varies between countries. Therefore, the current knowledge may not necessarily be illustrative of the Portuguese reality. In the other hand, our data could contribute to a global analysis regarding this disease.

Our aim is to describe the demographic characteristics, clinical course, management and outcomes of hospitalized patients with COVID-19 in a Portuguese tertiary center. As the pandemic is quickly evolving, we also sought to investigate potential risk factors for in-hospital mortality to further allow the development of prognostic models and tailor the daily clinical management of the individual patient.

\section{Material and Methods STUDY DESIGN AND PATIENTS}

This ambispective cohort study included all COVID-19 inpatients aged 18 years-old or older, admitted to Hospital de Santa Maria (Lisbon, Portugal). Patients were recruited from March $3^{\text {rd }}$ to August $3^{\text {rd }}$, 2020, first outbreak. Patients entered the study retrospectively and prospectively before and after $27^{\text {th }}$ of April. Patients were followed until they were discharged, lost to follow-up or died. All patients had a positive test for severe acute respiratory syndrome coronavirus 2 (SARS-CoV-2) by reverse transcriptase polymerase chain reaction. We have excluded asymptomatic patients, pregnant women, patients that were admitted due to another condition and all those who were hospitalized due to social/sanitary reasons (e.g., the inability for social isolation). Readmissions were also excluded (4 patients with more than 1 admission during this period). The clinical outcomes were recorded until September $3^{\text {rd }}$, 2020, corresponding to the day the last patient reached the primary outcome. The study was approved by the Hospital de Santa Maria's ethics committee ( $\left.N^{\circ} 178 / 20\right)$ in accordance with the Helsinki Declaration statements. The requirement for the written informed consent was waived.

\section{DATA COLLECTION}

Epidemiological, demographic and clinical data were obtained through clinical interviews and from electronic medical records. Data was collected using standardized data collection form and stored according to applicable legislation. Comorbidities and clinical data were either self-reported by the patients and/or extracted from all existing medical records. Laboratory and inpatient treatment modalities were assessed through patient electronic files and prescription software. The anonymity of patients was warranted.

\section{DEFINITIONS AND OUTCOME}

Presentation symptoms were considered until the third day of hospitalization. Fever was defined as tympanic temperature of at least $38.0^{\circ} \mathrm{C}$. Time of the first symptoms noticed was considered disease onset. Imaging and laboratory results corresponded to the first available result from admission until the third day of hospitalization. Patients were classified based on their performance status using the Clinical Frailty Scale $(\mathrm{CFS})^{7}$ as follows: autonomous (CFS 1-4), partially dependent (CFS 5-6) and totally dependent (CFS 7-9). Acute kidney injury was diagnosed according to Acute Kidney Injury Network criteria. ${ }^{8}$ Acute respiratory distress syndrome (ARDS) was diagnosed according to Berlin criteria. ${ }^{9}$ Acute lung injury (ALI) was diagnosed according to the American-European Consensus Conference on ARDS. ${ }^{10}$ Cancer included any type of active solid and/or hematological cancer under active surveillance and/or treatment. Cardiovascular disease (CVD) included all the following: aortic aneurysm disease, cardiomyopathy of any cause, coronary artery disease, heart failure of any cause, heart valve disease, peripheral artery disease and pulmonary hypertension. Chronic kidney disease (CKD) was diagnosed according to the "Kidney Disease: Improving Global Outcomes (KDIGO)". ${ }^{11}$ Obesity was defined as body mass index (BMI) equal or higher than $30 \mathrm{~kg} /$ $\mathrm{m}^{2}$. Radiological SARS-CoV-2 infection suggestive findings were as follows: chest radiography - unilateral or bilateral patchy pulmonary infiltrates and interstitial abnormalities; Chest computerized tomography (CT) scan - unilateral or bilateral pulmonary ground-glass abnormalities, honeycomb findings, organizing pneumonia. Clinical discharge was defined by concomitant absence of fever and oxygen requirements for at least 2 consecutive days. The outcome date was defined as the day of the patients' death or the hospital discharge date, due to clinical criteria. The total length of hospital stay was determined from the date of admission until the outcome 
date. The primary outcome was in-hospital all-cause mortality. Illness severity was accessed according to development of ARDS/ALI, intensive care unit (ICU) admission and invasive mechanical ventilation (IMV) need.

\section{STATISTICAL APPROACH}

We used STATA ${ }^{\circledR}$ (version 16) and SPSS ${ }^{\circ}$ software (version 26.0) for statistical analysis. Continuous and categorical variables were presented as median \pm interquartile range (IQR) and number (\%), respectively. We used the Mann-Whitney $U$ test, $\chi 2$ test or Fisher's exact test to compare differences between groups when appropriate. The minimum and maximum values will be shown whenever pertinent. We used univariable and multivariable logistic regression models to explore risk factors associated with the primary outcome. Variables were eligible for multivariable analysis if their between-group differences were significant. Patients were suppressed if they were lost to follow-up or reached the primary outcome. We considered a two-sided $\alpha$ of less than 0.05 as statistically significant.

\section{Results}

DEMOGRAPHICS, COMORBID CONDITIONS AND CLINICAL MANIFESTATIONS

Four hundred and thirty-two patients were admitted during the study period. After applying the exclusion criteria, 279 were eligible for further analysis (Fig. 1).

The baseline characteristics of our cohort are shown in Table 1. Fifty-seven percent of the patients $(n=159)$ were male, and the vast majority were of Caucasian ethnic origin (82.9\%). The median age was $69.0 \pm 26.0$ years. Most patients were independent (73.5\%), followed by totally dependent (16.2\%) and partially dependent (10.3\%) upon hospital admission. High blood pressure (HBP) was the most prevalent comorbid condition (66.3\%), followed by dyslipidemia (33.3\%), diabetes mellitus type 2 (27.1\%), cardiovascular disease (CVD) (26.5\%) and obesity (25.5\%). Nearly three-fourths of the patients $(74.4 \%)$ had fever before or during the first three days of hospitalization. Cough was reported in $67.0 \%$ of patients, followed by dyspnea (59.9\%), asthenia/fatigue (53.1\%) and generalized myalgia (30.8\%). The least frequent symptoms were, by descending order, anosmia (6.3\%), rhinorrhea (2.9\%), abdominal pain $(2.9 \%)$ and arthralgia (0.7\%). The median time from disease onset to hospital admission was $5.0 \pm 4.0$ days, ranging from 0 to 21 days (data not shown).

\section{RADIOLOGIC AND LABORATORY FINDINGS}

Of the 272 chest radiographies and 150 chest CT-scans that were performed at the time of admission, $76.1 \%$ and $88.7 \%$ revealed suggestive findings of SARS-CoV-2 infection, respectively. On admission, Iymphopenia (lymphocyte count $<1.0 \times 109 / L)$ was the most frequent blood count abnormality (45.7\%). Severe lymphopenia (lymphocyte count $\leq 0.5 \times 109 / L)$ was found in $8.3 \%$ of patients. D-dimer levels were higher than $0.25 \mu \mathrm{g} / \mathrm{mL}$ in $73.9 \%$ of patients, but only $21.0 \%$ presented values equal or higher than $1 \mu \mathrm{g} / \mathrm{mL}$. Most patients showed increased inflammatory markers: elevated ferritin levels in $86.3 \%$, C-reactive protein (CRP) in $74.8 \%$ and interleukin (IL) 6 in $60.5 \%$ of the patients.

\section{INPATIENT TREATMENT, CLINICAL COURSE AND OUT- COMES}

Antiviral therapy was the most frequently administered treatment (71.5\%), followed by hydroxychloroquine (52.8\%), steroids

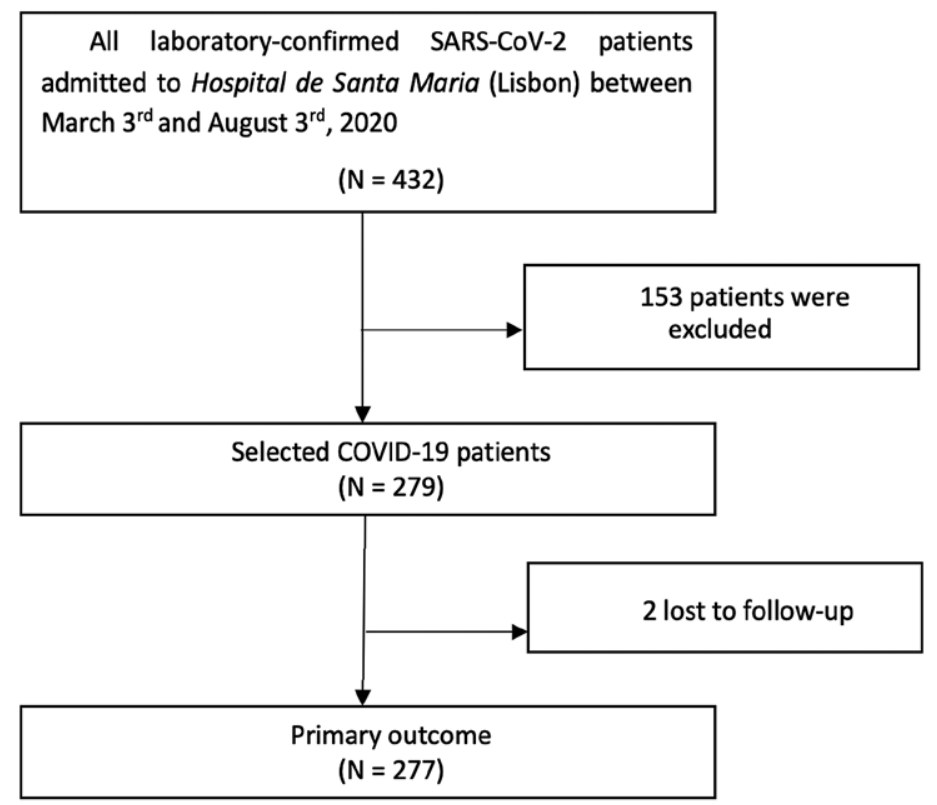

Figure 1: Patient selection scheme. 
(29.0\%) and tocilizumab (5.5\%). Antibiotic therapy was used in $49.5 \%$ of the patients. The time from disease onset and hospital admission to outcome was $17 \pm 12$ days and $10 \pm 13$ days respectively. During the study period, two patients were lost to follow-up and 48 patients (48/277, 17.3\%) died. Approximately $32 \%, 31.9 \%$ and $20.8 \%$ of patients developed ARDS/ALI, were admitted in the ICU and needed IMV, respectively. The timeframe for each secondary outcome is displayed in Table 1.

Table 1: Baseline characteristics description of all patients and comparison according to primary outcome of patients with COVID-19.
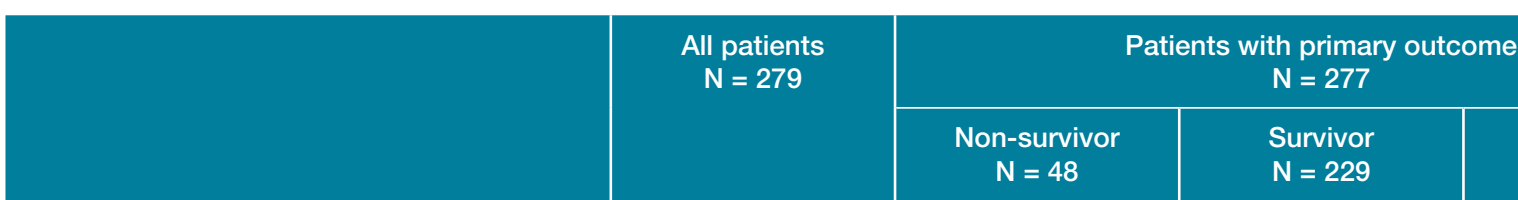

\section{Demographics}

Male sex

Age, years

Caucasian ethnic

Clinical frailty scale

$1-4$
$5-6$
$7-9$

\section{Comorbid conditions}

\begin{tabular}{l|c}
\hline Hypertension & $185(66.3)$ \\
\hline Dyslipidemia & $93(33.3)$ \\
\hline Diabetes mellitus type 2 & $76(27.1)$ \\
\hline Cardiovascular disease & $74(26.5)$ \\
\hline Obesity & $71(25.5)$ \\
Chronic kidney disease & $51(18.3)$ \\
Cerebrovascular disease & $49(17.6)$ \\
Chronic obstructive pulmonary disease & $37(13.3)$ \\
Cancer & $23(8.2)$ \\
Asthma & $15(5.4)$ \\
Rheumatic disease & $15(5.4)$ \\
HIV/AIDS & $5(1.8)$
\end{tabular}

\section{$159(57)$}

$69 \pm 26$

223/269 (82.9)

200/272 (73.5)

$28 / 272(10.3)$

44/272 (16.2)

\section{8 (58.3)}

$84.5 \pm 16.5$

$41 / 45(91.1)$

22/44 (47.7)

8/44 (18.2)

14/44 (31.8) $p$

0.842

$<0.001$

0.118

$0.004+$

176/226 (77.9)

20/226 (8.8)

30/226 (13.3)

\section{Symptoms}

Fever

Cough

Dyspnea

Asthenia

Myalgia

Diarrhea

Headache

Chest pain

Anorexia

Nausea/vomiting

Ageusia

Sore throat

Anosmia

Rhinorrhea

Abdominal pain

Arthralgia
206/277 (74.4)

185/276 (67.0)

166/277 (59.9)

146/275 (53.1)

84/273 (30.8)

$64 / 276(23.2)$

40/273 (14.7)

$37 / 273(13.6)$

$33 / 273(12.1)$

$32 / 276(11.6)$

21/271 (7.8)

18/272 (6.6)

17/271 (6.3)

8/273 (2.9)

8/274 (2.9)

2/273 (0.7)
$33 / 46(71.7)$

$29 / 45(64.4)$

$33 / 46(71.7)$

20/44 (45.5)

$5 / 44(11.4)$

$3 / 45(6.7)$

$4 / 44(9.1)$

$3 / 44(6.8)$

0

2/45 (4.4)

0

1/43 (2.3)

0

0

1/44 (2.3)

0

$144(62.9)$
$75(32.6)$
$59(25.8)$
$50(21.8)$
$63(27.5)$
$36(15.7)$
$35(15.3)$
$23(10.0)$
$17(7.4)$
$14(6.1)$
$15(6.6)$
$4(1.8)$

0.006

0.938

0.283

$<0.001$

0.029

0.012

0.022

$<0.001$

0.246

0.262

NA

NA 
Table 1 (cont.): Baseline characteristics description of all patients and comparison according to primary outcome of patients with COVID-19.
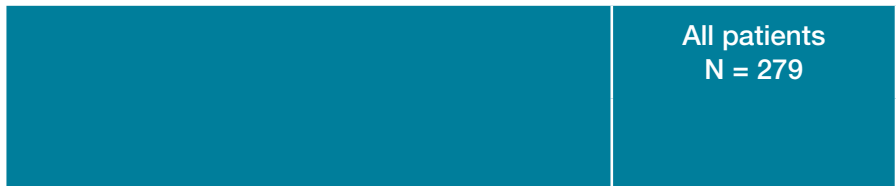

\begin{tabular}{|c|c|}
\hline \multicolumn{2}{|c|}{ Patients with primary outcom } \\
$\mathrm{N}=277$ \\
\hline $\begin{array}{c}\text { Non-survivor } \\
\mathrm{N}=48\end{array}$ & Survivor \\
$\mathrm{N}=229$
\end{tabular}

\section{Laboratory results}

Hb, M: $<13 \mathrm{~g} / \mathrm{dL} / \mathrm{F}:<12 \mathrm{~g} / \mathrm{dL}$

Leucocyte, $>11 \times 109 / \mathrm{L}$

Neutrophil, $>7.5 \times 109 / \mathrm{L}$

Lymphocyte, <1000 x109/L

$500-1000 \times 109 / L$

$\leq 500 \times 10^{\wedge} 9 / L$

Absolute value, $\times 109 / L$

Monocyte, >1000 ×109/L

Platelet count, <150 ×109/L

100-150 x109/L

$\leq 100 \times 109 / L$

D-dimer, $>0.25 \mu \mathrm{g} / \mathrm{mL}$

$\leq 0.5 \mu \mathrm{g} / \mathrm{mL}$

$0.5-1 \mu \mathrm{g} / \mathrm{mL}$

$\geq 1 \mu \mathrm{g} / \mathrm{mL}$

Acute kidney injury

Sodium, <135 mmOI/L

AST, $>40 \mathrm{U} / \mathrm{L}$

$\mathrm{ALT},>41 \mathrm{U} / \mathrm{L}$

Total bilirubin, $>1.2 \mathrm{mg} / \mathrm{dL}$

Creatin kinase, $>300 \mathrm{U} / \mathrm{L}$

$\mathrm{LDH},>250 \mathrm{U} / \mathrm{L}$

Albumin, $<3 \mathrm{~g} / \mathrm{dL}$

Troponin T, $>14 \mu \mathrm{g} / \mathrm{mL}$

$\mathrm{CRP},>5 \mathrm{mg} / \mathrm{dL}$

$\leq 10 \mathrm{mg} / \mathrm{dL}$

$10-20 \mathrm{mg} / \mathrm{dL}$

$\geq 20 \mathrm{mg} / \mathrm{dL}$

Absolute value, mg/dL

Procalcitonin, $>2$ mg/dL

Ferritin, $>300 \mathrm{ng} / \mathrm{mL}$ )

300-1000 ng/mL

$>1000 \mathrm{ng} / \mathrm{mL}$

Absolute value, $\mathrm{ng} / \mathrm{mL}$

IL-6, > 40 UNIT

Absolute value, UNIT

90/278 (32.4)

40/278 (14.4)

$75 / 278$ (27)

126/276 (45.7)

103/276 (37.3)

23/276 (8.3)

$1060 \pm 600$

10/272 (3.7)

$67 / 276$ (24.3)

$58 / 276(21.0)$

9/276 (3.3)

190/257 (73.9)

78/257 (30.4)

$58 / 257$ (22.6)

$54 / 257$ (21.0)

94/269 (34.9)

85/275 (30.9)

103/274 (37.6)

$60 / 274$ (21.9)

9/242 (3.7)

$53 / 246(21.5)$

223/272 (82)

27/215 (12.6)

121/226 (53.5)

208/278 (74.8)

83/278 (29.9)

$76 / 278$ (27.3)

49/278 (17.6)

$$
9.3 \pm 12.4
$$

18/261 (6.9)

158/183 (86.3)

85/183 (46.5)

73/183 (39.9)

$789 \pm 1104$

46/76 (60.5)

$54 \pm 73$
$22(45.8)$

16 (33.3)

21 (43.8)

$29(60.4)$

19 (39.6)

$10(20.8)$

$870 \pm 540$

3 (6.3)

16 (33.3)

14 (29.2)

2 (4.2)

$39 / 40(97.5)$

14/40 (35.0)

$5 / 40(12.5)$

20/40 (50.0)

23/44 (52.3)

12/47 (25.5)

17 (35.4)

$9(18.8)$

1/38 (2.6)

$7 / 43$ (16.3)

39/47 (83)

8/37 (21.6)

33/42 (78.6)

39 (81.3)

11 (22.9)

$13(27.1)$

15 (31.3)

$13 \pm 16.2$

5/42 (11.9)

22/28 (78.6)

13/28 (46.4)

$9 / 28$ (32.1)

$564.5 \pm 2231$

8/9 (88.9)

$145.4 \pm 95.7$
68/228 (29.8)

23/228 (10.1)

$52 / 228(22.8)$

97/227 (42.7)

84/227 (37.0)

13/227 (5.7)

$1080 \pm 610$

7/223 (3.1)

$51 / 227$ (22.5)

44/227 (19.4)

$7 / 227$ (3.1)

149/215 (69.3)

63/215 (29.3)

$52 / 215$ (24.2)

$34 / 215$ (15.8)

$71 / 223(31.8)$

$73 / 227$ (32.2)

$86 / 225$ (38.2)

$51 / 225(22.7)$

8/203 (3.9)

45/201 (22.4)

$183 / 224(81.7)$

19/177 (10.7)

88/183 (48.1)

167/228 (73.3)

$72 / 228$ (31.6)

$62 / 228(27.2)$

$33 / 228$ (14.5)

$9.1 \pm 11.8$

$13 / 218(6)$

135/154 (87.7)

$71 / 154(46.1)$

64/182 (41.6)

$841 \pm 1103$

$37 / 66(56.1)$

$48 \pm 47.8$ $p$

\section{Radiological findings}

Suggestive chest $\mathrm{x}$-ray

Suggestive chest CT-scan

207/272 (76.1)

$37 / 46(80.4)$

168/224 (75.0)

0.432

133/150 (88.7)

$17 / 20(85.0)$

$115 / 128(89.8)$

0.516 
Table 1 (cont.): Baseline characteristics description of all patients and comparison according to primary outcome of patients with COVID-19.

\begin{tabular}{|c|c|c|c|c|}
\hline & \multirow[t]{2}{*}{$\begin{array}{c}\text { All patients } \\
\mathrm{N}=279\end{array}$} & \multicolumn{3}{|c|}{$\begin{array}{l}\text { Patients with primary outcome } \\
\qquad N=277\end{array}$} \\
\hline & & $\begin{array}{c}\text { Non-survivor } \\
\mathrm{N}=48\end{array}$ & $\begin{array}{l}\text { Survivor } \\
\mathrm{N}=229\end{array}$ & $p$ \\
\hline \multicolumn{5}{|l|}{ Inpatient medication (ever) } \\
\hline Hydroxychloroquine & $143 / 271(52.8)$ & 26/42 (61.9) & $115 / 227(50.7)$ & 0.180 \\
\hline Anti-viral therapy & 193/270 (71.5) & 25/42 (59.5) & 166/226 (73.5) & 0.067 \\
\hline Lopinavir/ritonavir & $177 / 270(65.6)$ & 25/42 (59.5) & $150 / 226(66.4)$ & 0.392 \\
\hline Remdesivir & $21 / 270(7.8)$ & 0 & 21/226 (9.4) & NA \\
\hline Antibiotics & 135/273 (49.5) & 30/43 (69.8) & 103/228 (45.2) & 0.003 \\
\hline Tocilizumab & 15/272 (5.5) & $1 / 43(2.3)$ & $13 / 227(5.7)$ & 0.705 \\
\hline Steroids & $78 / 269$ (29.0) & 10/39 (25.6) & $67 / 228(29.4)$ & 0.633 \\
\hline \multicolumn{5}{|l|}{ Timeframes } \\
\hline Time from disease onset to admission, days & $5(4)$ & $3(4)$ & $6(4)$ & 0.008 \\
\hline Time from disease onset to outcome, days & $17(12)$ & $12(22)$ & $17(11)$ & 0.025 \\
\hline Time from admission to outcome, days & $10(13)$ & $7.5(16)$ & $11(11)$ & 0.120 \\
\hline \multicolumn{5}{|l|}{ Severity outcomes } \\
\hline ARDS/ALI & $87 / 269$ (32.3) & 24/41 (58.5) & $62 / 226(27.4)$ & $<0.001$ \\
\hline Time from disease onset to ARDS, days & $9 \pm 7$ & $7.5 \pm 7$ & $9 \pm 7$ & 0.537 \\
\hline Time from admission to ARDS, days & $4 \pm 5$ & $4 \pm 5.5$ & $4 \pm 4$ & 0.698 \\
\hline ICU admission & $89(31.9)$ & $22(45.8)$ & $66(28.8)$ & 0.021 \\
\hline Time from disease onset to ICU, days & $8 \pm 5$ & $6 \pm 4$ & $8 \pm 4$ & 0.256 \\
\hline Time from admission to $\mathrm{ICU}$, days & $2 \pm 3$ & $1 \pm 3$ & $2 \pm 2$ & 0.734 \\
\hline Duration, days & $12 \pm 25$ & $19.5 \pm 29$ & $12 \pm 22$ & 0.681 \\
\hline IMV & $58(20.8)$ & 16 (33.3) & $41(17.9)$ & 0.016 \\
\hline Time from disease onset to IMV, days & $8 \pm 5$ & $8 \pm 5$ & $8 \pm 6$ & 0.545 \\
\hline Time from admission to IMV, days & $2 \pm 4$ & $2 \pm 3.5$ & $3 \pm 4$ & 0.703 \\
\hline Duration, days & $16 \pm 21$ & $26 \pm 29$ & $14 \pm 19$ & 0.302 \\
\hline
\end{tabular}

Data is shown as number (\%) for categorical variables and median \pm interquartile range for continuous variables. The denominators of patients who were included in the analysis are provided if it differed from the overall numbers within the group. AIDS, acquired immunodeficiency syndrome; ALI, acute lung injury; ALT, alanine aminotransferase; ARDS, acute respiratory distress syndrome; CRP, c-reactive protein; CT-scan, computerized tomography scan; F, female; ICU, intensive care unit; IL-6, interleukin 6; IMV, invasive mechanical ventilation; M, male

$+\chi 2$ test comparing all subcategories.

\section{MORTALITY AND SEVERE DISEASE DETERMINANTS}

Patients who died were older $(84.5 \pm 16.5$ vs $67.0 \pm 25.0$ years, $p<0.001$ ) and had higher proportion of high CFS (CFS $\geq 5,50.0 \%$ vs $22.1 \%, p=0.004$ ). Gender (male, $56.8 \%$ vs. $58.3 \%, p=0.842$ ) and the frequency of Caucasian ethnicity $(81.5 \%$ vs $91.1 \%, p=0.118)$ were equally distributed between survivors and non-survivors. Time from symptom onset to hospital admission $(3.0 \pm 4.0$ vs $6.0 \pm 4.0$ days, $p$ $=0.008)$, symptom onset to outcome $(12.0 \pm 22.0 \mathrm{vs} 17.0$ \pm 11.0 days, $p=0.025)$, but not from hospital admission to outcome (7.5 \pm 16.0 vs $11.0 \pm 11.0$ days, $p=0.120)$, were significantly shorter in the non-survivor compared to survivor group.
$\operatorname{HBP}(83.3 \%$ vs 62.9\%, $p=0.006)$, CVD (50.0\% vs $21.8 \%$, $p<0.001), \operatorname{CKD}(31.3 \%$ vs $15.7 \%, p=0.012)$ and chronic obstructive pulmonary disease (COPD) (29.2\% vs 10.0\%, $p<$ 0.001 ) were significantly more prevalent in COVID-19 patients who died compared to those who survived. Obesity was the only comorbid condition that was significantly more prevalent in the survivor group (27.5\% vs $12.5 \%, p=.029)$. Symptoms were similarly reported by survivors and non-survivors, except for generalized myalgia (34.4\% vs $11.4 \%, p=0.002)$ and diarrhea $(26.6 \%$ vs $6.7 \%, p=0.004)$ that were significantly more prevalent in the survivors compared to non-survivors. Patients who died had higher proportion of anemia (45.8\% vs $29.8 \%$, $p=0.032$ ), leukocytosis (33.3\% vs $10.1 \%, p<0.001)$, severe 
lymphopenia (20.8\% vs 5.7\%, $p=0.001$ ) and d-dimer levels equal or higher than $1 \mu \mathrm{g} / \mathrm{mL}$ (50.0\% vs $15.8 \%, p<0.001)$. Regarding the inflammatory markers, only the median plasma level of CRP $(13.0 \pm 16.2$ vs $9.1 \pm 11.8 \mathrm{mg} / \mathrm{dL}, p=0.025)$ and IL-6 levels ( $145.4 \pm 95.7$ vs $48.0 \pm 47.8 \mathrm{pg} / \mathrm{mL}, p=0.004)$, but not ferritin levels $(564.5 \pm 2231.0$ vs $841.0 \pm 1103.0 \mathrm{ng} / \mathrm{mL}$, $p=0.578$ ), differed significantly between these two groups. Finally, in-patient treatments were similarly distributed between all patients. Only the proportion of antibiotic administration differed between the non-survivors and survivors $(69.8 \%$ vs $45.2 \%, p=0.003)$.

Table 2 displays the risk factors associated with in-hospital mortality.

In univariable analysis, the odds of in-hospital death were higher in patients with $\mathrm{HBP}(\mathrm{OR} 2.95,95 \% \mathrm{Cl} 1.32-6.60, p=$ 0.008), CVD (OR 3.58, 95\% Cl $1.87-6.84, p<0.001$ ), cerebrovascular disease (OR 2.28, 95\% Cl 1.11-4.68, $p=0.024)$, CKD (OR2.44, 95\% Cl $1.20-4.94, p=0.013$ ) and COPD (OR $3.69,95 \% \mathrm{Cl} 1.73-7.86, p=0.001)$. Conversely, obesity was not associated with the odds of death (OR 0.38, 95\% Cl 0.15 - 0.93). Age (per-unit increase OR 1.06, 95\% Cl 1.03-1.08, $p$ $<0.001$ ), anaemia (OR 1.99, 95\% Cl 1.06 - 3.76, $p=0.033$ ), white blood cell count $>11 \times 109 / \mathrm{L}$ (OR 4.46, 95\% Cl $2.13-$ 9.33, $p<0.001$ ), neutrophil count $>7.5 \times 109 / \mathrm{L}$ (OR 2.63, 95\% Cl 1.38 -5.04, $p=0.003$ ), lymphocyte count $\leq 0.5 \times 109 / L$ (OR 4.33, 95\% Cl $1.77-10.59, p=0.001)$, d-dimer $\geq 1 \mu \mathrm{g} / \mathrm{mL}$ (OR $5.32,95 \% \mathrm{Cl} 2.59-10.94, p<0.001$ ), CRP (per-unit increase OR 1.04, 95\% Cl $1.00-1.07, p=0.024$ ) and IL-6 (per-unit increase OR 1.01, 95\% Cl $1.00-1.02, p=0.031$ ) levels at admission were also significantly associated with death. In multivariable analysis, we found that age, CVD and severe lymphopenia maintained their significant association with the odds of death. Noteworthy, after several multivariable arrangements, the use of antibiotics was not associated with the odds of dying (data not shown).

\section{Discussion}

To the best of our knowledge, this is one of the first studies to analyze a cohort of adult inpatients with COVID-19 in Portugal and to identify several risk factors for in-hospital death in this population. We believe that this data brings insightful information about hospitalized patients with COVID-19 from the first pandemic outbreak in our country.

We report a similar prevalence of the most frequent comorbidities, namely HBP, dyslipidemia, diabetes, CVD and obesity, regarding most European studies. ${ }^{4,5,12,13}$ The high prevalence of these cardiovascular diseases is systematically reported and frequently associated with adverse outcomes in COVID-19 patients. , $3-5,12,14$ Patients with such diseases, usually older, tend to decompensate their chronic illnesses and seek for medical care. The overrepresented proportion of some of these comorbid conditions may, therefore, arise from a possible selection bias in most studies. We also observed that HBP, CKD, COPD and especially CVD were associated with an increase in the risk of death in our cohort. Despite the recognized negative impact of obesity in the clinical course of COVID-19 patients, ${ }^{15}$ we were surprised to find that obesity was associated with lower risk for death in our patients (OR 0.38, 95\% Cl 0.15 $0.93, p=0.034)$. Even though we report a similar prevalence of obesity as our last national enquiry, ${ }^{16}$ we believe we might lack sensitivity compared to others who have reported obesity in categories ${ }^{13}$ and even as continuous values of BMI. ${ }^{17}$

In our cohort, the most frequent symptoms upon admission were fever, cough, dyspnea and asthenia, which were similar to those reported in other studies. ${ }^{1-5,12,14}$ Unlike us, some authors have described those symptoms more frequently among non-survivors. ${ }^{9}$ On the other hand, we report nausea, anosmia, ageusia and generalized myalgia less frequently. These symptoms are associated with milder forms of disease, usually in patients that do not require hospitalization. ${ }^{6}$ The median time from disease onset to hospital admission was in accordance with published data. ${ }^{18}$ Similarly to others, we have noticed that deceased patients are admitted at an earlier stage of the disease and have a shorter hospital stay, suggesting a more severe initial presentation and faster deterioration. ${ }^{1,17}$

The positive relationship between a higher mortality and some laboratory markers, such as increased CRP, IL-6 and d-dimer, has already been reported 1 and might reflect the hyperinflammatory state known to occur in severe SARS-CoV-2 infections. ${ }^{19}$ Moreover, our results show that not only lymphopenia was associated with mortality, but also the increase in the total leukocyte count and, more importantly, neutrophil count, were also associated with death. We did not calculate the neutrophil-to-lymphocyte ratio, which has been increasingly recognized as an important predictor of severity and mortality in other studies. ${ }^{20,21}$ However, it remains difficult to interpret it as simply a sign of a superimposed bacterial infection22,23 or a surrogate of a dysregulated immune response, ${ }^{21}$ by which COVID-19 is known for. ${ }^{19,21,24}$

Treatment options were empirical and experimental based. In our institution, the inpatient treatment regimens were in line with other studies ${ }^{1,2,4,5,25}$ and international recommendations at that time. It is now known that no benefit was observed with lopinavir-ritonavir treatment when compared to supportive care in hospitalized adult patients with severe COVID-19. ${ }^{26}$ Therefore, we were not surprised to observe that these antiviral therapies did not change the risk of mortality in our study. The same is also true for remdesivir that had little or no effect on hospitalized patients with COVID-19 according to recent clinical trials. ${ }^{27}$ In our sample, we cannot comment on the effectiveness of remdesivir due to the small number of cases treated with remdesivir.

Frailty scores are frequently used in clinical decision-making, yet they are scarcely reported in most COVID-19 series. Despite their age, nearly three-quarters of our patients were considered fit or vulnerable, but not frail, according to 
Table 2: Risk factors for in-hospital mortality.

\begin{tabular}{|c|c|c|c|c|}
\hline & Univariable OR $(95 \% \mathrm{Cl})$ & $p$ & Multivariable OR $(95 \% \mathrm{Cl})$ & $p$ \\
\hline \multicolumn{5}{|l|}{ Demographics } \\
\hline $\begin{array}{l}\text { Male sex } \\
\text { Age, years } \\
\text { Caucasian ethnic } \\
\text { Clinical frailty scale* }\end{array}$ & $\begin{array}{l}1.07(0.57-2.00) \\
1.06(1.03-1.08) \\
2.32(0.79-6.85) \\
1.39(1.19-1.62)\end{array}$ & $\begin{array}{c}0.842 \\
<0.001 \\
0.127 \\
<0.001\end{array}$ & $\begin{array}{c}- \\
1.04(1.01-1.09) \\
- \\
1.03(0.82-1.30)\end{array}$ & $\begin{array}{c}- \\
0.023 \\
- \\
0.799\end{array}$ \\
\hline \multicolumn{5}{|l|}{ Comorbid conditions } \\
\hline $\begin{array}{l}\text { High blood pressure } \\
\text { Dyslipidemia } \\
\text { Diabetes mellitus } \\
\text { Obesity } \\
\text { Cardiovascular disease } \\
\text { Cerebrovascular disease } \\
\text { Chronic kidney disease } \\
\text { Chronic obstructive pulmonary disease } \\
\text { Cancer } \\
\text { Asthma } \\
\text { Rheumatic disease } \\
\text { HIV/AIDS }\end{array}$ & $\begin{array}{l}2.95(1.32-6.60) \\
1.03(0.53-1.99) \\
1.44(0.74-2.81) \\
0.38(0.15-0.93) \\
3.58(1.87-6.84) \\
2.28(1.11-4.68) \\
2.44(1.20-4.94) \\
3.69(1.73-7.86) \\
1.78(0.66-4.78) \\
0.33(0.04-2.55) \\
\text { NA } \\
\text { NA }\end{array}$ & $\begin{array}{c}0.008 \\
0.938 \\
0.285 \\
0.034 \\
<0.001 \\
0.024 \\
0.013 \\
0.001 \\
0.252 \\
0.286 \\
\text { NA } \\
\text { NA }\end{array}$ & $\begin{array}{c}- \\
- \\
- \\
- \\
2.68(1.21-5.93) \\
- \\
- \\
2.19(0.88-5.44) \\
- \\
- \\
-\end{array}$ & $\begin{array}{c}- \\
- \\
- \\
- \\
0.015 \\
- \\
- \\
0.090 \\
- \\
- \\
- \\
-\end{array}$ \\
\hline \multicolumn{5}{|l|}{ Laboratory results } \\
\hline $\begin{array}{l}\text { Hb, M: <13.0 g/dL / F: }<12.0 \mathrm{~g} / \mathrm{dL} \\
\text { Leucocyte, }>11.0 \times 10 \wedge \mathrm{g} / \mathrm{L} \\
\text { Neutrophil, }>7.5 \times 109 / \mathrm{L} \\
\text { Lymphocyte, }<0.5 \times 109 / \mathrm{L} \\
\text { Monocyte, }>1.0 \times 10 \wedge 9 / \mathrm{L} \\
\text { Platelet count, }<150 \times 10 \wedge \mathrm{g} / \mathrm{L} \\
\text { D-dimer, } \geq 1 \mu \mathrm{gg} / \mathrm{mL} \\
\text { Acute kidney injury } \\
\text { Sodium, }<135 \mathrm{mmol} / \mathrm{L} \\
\text { AST, }>40 \text { U/L } \\
\text { ALT, }>41 \mathrm{U} / \mathrm{L} \\
\text { Total bilirubin, }>1.2 \mathrm{mg} / \mathrm{dL} \\
\text { Creatine kinase, }>300 \mathrm{U} / \mathrm{L} \\
\text { LDH, }>250 \mathrm{U} / \mathrm{L} \\
\text { Albumin, }<3.0 \mathrm{~g} / \mathrm{dL} \\
\text { Troponin T, }>14 \mathrm{ng} / \mathrm{L} \\
\text { CRP, } \geq 20 \mathrm{mg} / \mathrm{dL} \\
\text { Absolute value, } \mathrm{mg} / \mathrm{mL}^{*} \\
\text { Procalcitonin, }>2 \mathrm{ng} / \mathrm{mL} \\
\text { Ferritin, Absolute value, } \mathrm{ng} / \mathrm{mL}^{*} \\
\text { IL-6, Absolute value, pg/mL* }\end{array}$ & $\begin{array}{l}1.99(1.06-3.76) \\
4.46(2.13-9.33) \\
2.63(1.38-5.04) \\
4.33(1.77-10.59) \\
2.06(0.51-8.26) \\
1.73(0.87-3.39) \\
5.32(2.59-10.94) \\
2.34(1.22-4.51) \\
0.72(0.35-1.47) \\
0.89(0.46-1.7) \\
0.79(0.36-1.73) \\
0.66(0.08-5.42) \\
0.67(0.28-1.62) \\
1.09(0.47-2.51) \\
2.29(0.92-5.73) \\
3.96(1.79-8.74) \\
2.69(1.32-5.48) \\
1.04(1.00-1.07) \\
2.13(0.72-6.33) \\
1.00(0.99-1.00) \\
1.01(1.00-1.02)\end{array}$ & $\begin{array}{c}0.033 \\
<0.001 \\
0.003 \\
0.001 \\
0.309 \\
0.114 \\
<0.001 \\
0.011 \\
0.373 \\
0.716 \\
0.553 \\
0.698 \\
0.377 \\
0.836 \\
0.076 \\
0.001 \\
0.007 \\
0.024 \\
0.173 \\
0.228 \\
0.031\end{array}$ & $\begin{aligned} &- \\
&-- \\
& 6.61(2.23-19.62) \\
&- \\
&- \\
&- \\
&- \\
&- \\
&- \\
&- \\
&- \\
&- \\
&- \\
&- \\
&- \\
&- \\
&- \\
&-\end{aligned}$ & $\begin{array}{l}- \\
- \\
- \\
0.001 \\
- \\
- \\
- \\
- \\
- \\
- \\
- \\
- \\
- \\
- \\
- \\
- \\
- \\
- \\
- \\
- \\
-\end{array}$ \\
\hline \multicolumn{5}{|l|}{ Inpatient medication } \\
\hline $\begin{array}{l}\text { Hydroxychloroquine } \\
\text { Anti-viral therapy (total) } \\
\text { Lopinavir/ritonavir } \\
\text { Remdesivir } \\
\text { Antibiotics } \\
\text { Tocilizumab } \\
\text { Steroids }\end{array}$ & $\begin{array}{c}1.58(0.81-3.11) \\
0.53(0.27-1.05) \\
0.75(0.38-1.46) \\
N A \\
2.80(1.39-5.65) \\
0.39(0.05-3.08) \\
0.83(0.38-1.8)\end{array}$ & $\begin{array}{l}0.182 \\
0.070 \\
0.393 \\
N A \\
0.004 \\
0.373 \\
0.634\end{array}$ & $\begin{array}{l}- \\
- \\
- \\
- \\
- \\
- \\
-\end{array}$ & $\begin{array}{l}- \\
- \\
- \\
- \\
- \\
-\end{array}$ \\
\hline
\end{tabular}

*per-unit increase; ALT, alanine aminotransferase; CRP, c-reactive protein; F, female; HIV/AIDS, human immunodeficiency virus/acquired immunodeficiency syndrome; IL-6, interleukin 6; M, male 
the CFS, and this difference was even more pronounced when we compared survivors with non-survivors (CFS 1-4, 77.9\% vs $47.7 \%, p=0.004)$. The impact of CFS on disease outcomes was even more significant $(p<0.001)$ in a logistic model, further supporting its' applicability in clinical practice as has been stated by others. ${ }^{28}$

Our cohort was composed predominantly by Caucasian males which is in conformity with the majority of published European series demographic characteristics. Age is one of the most important risk factors for mortality. Accordingly, we also found a significant relationship between age and death, with an increase of $60 \%$ in the chance of dying for every 10 years increase in age (Table 2). The median age of our patients was 69 years, which is higher compared to data from China $^{2}$ (47 years) and from the USA3 (63 years). This disparity between median ages is probably related to our inclusion/exclusion criteria and to the fact that the Portuguese population is remarkably older when compared to other European and non-European countries.

In our series, the in-hospital mortality rate was 17.3\%. Even though population-based studies ${ }^{13}$ tend to have lower mortality rates than hospital-centered ones, and despite our rigorous patient selection criteria, we still report a lower mortality rate than other in-patient series, like New York's (21\%), ${ }^{3}$ Wuhan's (28.3\%), ${ }^{1}$ the United Kingdom's (37\%) ${ }^{12}$ and Italy's (43.6\%). ${ }^{5}$ In a large multicenter retrospective study from Spain, Casas-Rojo JM et a/ ${ }^{4}$ showed that $21 \%$ have died and only $8.3 \%$ were admitted to the ICU. The ARDS prevalence was similar to ours (32.2\% vs 33.1\%). Even though our results are not as representative as theirs when it comes to cohort size, we consider that these differences with regard to mortality, but also to other severity outcomes, deserves a special attention, as we share many demographic characteristics, living conditions and access to health care facilities with the Spanish population. These differences could be explained by the different timing and magnitude of the pandemic and its pressure on the healthcare system, which was earlier and more devastating compared to Portugal, giving us an advantage in applying timely confinement measures during this first outbreak. Although the Portuguese's national health system has the lowest ratio of number of ICU beds per 100000 inhabitants (4.2) and one of the lowest number of ventilators (1400) in the European Union, our hospitals were never on the verge of rupture during this first wave of the pandemic, compared to Spain, France and Italy.

Our study has several limitations. First, despite our active role as clinicians, we were not able to have a direct interaction with all patients, neither did we have control over which laboratory or imaging exams were performed, hence some data are missing. Secondly, our restricted sample size limits the interpretation of our findings and may not be representative of our total national data. We also have some strengths. As all our patients have finished the study, our mortality rate is accurate. Furthermore, the ambispective nature of the study warrants some preciseness in data collection. Finally, we highlight the role of fragility as an important risk factor to be taken into account.

\section{Conclusion}

In conclusion, the present work represents one of the first studies describing and analyzing the demographic, clinical characteristics and outcomes of hospitalized patients with COVID-19 in Portugal. We found similar clinical presentation symptoms and comorbid conditions as those reported internationally, some of them clearly linked with an increased risk of death, namely CVD and COPD. In addition to age, the potential use of a frailty scale as a prognostic factor should help clinicians to identify patients with poor prognosis at an early stage. We report a lower mortality rate compared to studies in hospitals in other countries during the first outbreak.

\section{Responsabilidades Éticas}

Conflitos de Interesse: Os autores declaram a inexistência de conflitos de interesse na realização do presente trabalho.

Fontes de Financiamento: Não existiram fontes externas de financiamento para a realização deste artigo.

Confidencialidade dos Dados: Os autores declaram ter seguido os protocolos da sua instituição acerca da publicação dos dados de doentes. Proteção de Pessoas e Animais: Os autores declaram que os procedimentos seguidos estavam de acordo com os regulamentos estabelecidos pelos responsáveis da Comissão de Investigação Clínica e Ética e de acordo com a Declaração de Helsínquia da Associação Médica Mundial. Proveniência e Revisão por Pares: Não comissionado; revisão externa por pares.

\section{Ethical Disclosures}

Conflicts of interest: The authors have no conflicts of interest to declare. Financing Support: This work has not received any contribution, grant or scholarship

Confidentiality of Data: The authors declare that they have followed the protocols of their work center on the publication of data from patients.

Protection of Human and Animal Subjects: The authors declare that the procedures followed were in accordance with the regulations of the relevant clinical research ethics committee and with those of the Code of Ethics of the World Medical Association (Declaration of Helsinki).

Provenance and Peer Review: Not commissioned; externally peer reviewed.

(c) Autor (es) (ou seu (s) empregador (es)) e Revista SPMI 2021. Reutilização permitida de acordo com CC BY-NC. Nenhuma reutilização comercial. (c) Author(s) (or their employer(s)) and SPMl Journal 2021. Re-use permitted under CC BY-NC. No commercial re-use.

\section{Correspondence / Correspondência:}

Pedro Gaspar - pedrosilvagaspar@gmail.com

Serviço de Medicina 2, Hospital de Santa Maria, Centro Hospitalar Universitário Lisboa Norte, Portugal

Av. Prof. Egas Moniz MB, 1649-028 Lisboa 
Received / Recebido: 21/01/2021

Accepted / Aceite: 25/03/2021

Publicado / Published: 18 de junho de 2021

\section{REFERENCES}

1. Zhou F, Yu T, Du R, Fan G, Liu Y, Liu Z, et al. Clinical course and risk factors for mortality of adult inpatients with COVID-19 in Wuhan, China: a retrospective cohort study. The Lancet. 2020;395:1054-62.

2. Guan W, Ni Z, Hu Y, Liang W, Ou C, He J, et al. Clinical Characteristics of Coronavirus Disease 2019 in China. N Engl J Med. 2020;382:1708-20.

3. Richardson S, Hirsch JS, Narasimhan M, Crawford JM, McGinn T, Davidson KW, et al. Presenting Characteristics, Comorbidities, and Outcomes Among 5700 Patients Hospitalized With COVID-19 in the New York City Area. JAMA. 2020;323:2052.

4. Casas-Rojo JM, Antón-Santos JM, Millán-Núñez-Cortés J, Lumbreras-Bermejo C, Ramos-Rincón JM, Roy-Vallejo E, et al. Características clínicas de los pacientes hospitalizados con COVID-19 en España: resultados del Registro SEMI-COVID-19. Rev Clín Esp. 2020;220:480-94.

5. Vena A, Giacobbe DR, Di Biagio A, Mikulska M, Taramasso L, De Maria A, et al. Clinical characteristics, management and in-hospital mortality of patients with coronavirus disease 2019 in Genoa, Italy. Clin Microbiol Infect. 2020;26:1537-44.

6. Lapostolle F, Schneider E, Vianu I, Dollet G, Roche B, Berdah J, et al. Clinical features of 1487 COVID-19 patients with outpatient management in the Greater Paris: the COVID-call study. Intern Emerg Med. 2020;15:813-7.

7. Rockwood K. A global clinical measure of fitness and frailty in elderly people. Can Med Assoc J. 2005;173:489-95.

8. Mehta RL, Kellum JA, Shah SV, Molitoris BA, Ronco C, Warnock DG, et al. Acute Kidney Injury Network: report of an initiative to improve outcomes in acute kidney injury. Crit Care. 2007;11:R31.

9. ARDS Definition Task Force, Ranieri VM, Rubenfeld GD, Thompson BT, Ferguson ND, Caldwell E, et al. Acute respiratory distress syndrome: the Berlin Definition. JAMA. 2012;307:2526-33. doi: 10.1001/jama.2012.5669.

10. Bernard GR, Artigas A, Brigham KL, Carlet J, Falke K, Hudson L, et al. The American-European Consensus Conference on ARDS. Definitions, mechanisms, relevant outcomes, and clinical trial coordination. Am J Respir Crit Care Med. 1994;149:818-24.

11. Levey AS, Eckardt K-U, Tsukamoto Y, Levin A, Coresh J, Rossert J, et al. Definition and classification of chronic kidney disease: A position statement from Kidney Disease: Improving Global Outcomes (KDIGO). Kidney Int. 2005;67:2089-100.

12. Docherty AB, Harrison EM, Green CA, Hardwick HE, Pius R, Norman L, et al. Features of 20133 UK patients in hospital with covid-19 using the ISARIC WHO Clinical Characterisation Protocol: prospective observational cohort study. BMJ. 2020;m1985.

13. Williamson EJ, Walker AJ, Bhaskaran K, Bacon S, Bates C, Morton CE, et al. Factors associated with COVID-19-related death using OpenSAFELY.
Nature. 2020;584:430-6.

14. Wang D, Hu B, Hu C, Zhu F, Liu X, Zhang J, et al. Clinical Characteristics of 138 Hospitalized Patients With 2019 Novel Coronavirus-Infected Pneumonia in Wuhan, China. JAMA. 2020;323:1061.

15. Hussain A, Mahawar K, Xia Z, Yang W, EL-Hasani S. Obesity and mortality of COVID-19.Meta-analysis. Obes Res Clin Pract. 2020;14:295-300.

16. Gaio V, Antunes L, Namorado S, Barreto M, Gil A, Kyslaya I, et al. Prevalence of overweight and obesity in Portugal: Results from the First Portuguese Health Examination Survey (INSEF 2015). Obes Res Clin Pract. 2018;12:40-50

17. Perez-Guzman PN, Daunt A, Mukherjee S, Crook P, Forlano R, Kont MD, et al. Clinical Characteristics and Predictors of Outcomes of Hospitalized Patients With Coronavirus Disease 2019 in a Multiethnic London National Health Service Trust: A Retrospective Cohort Study. Clin Infect Dis. 2020;ciaa1091.

18. Li J, Huang DQ, Zou B, Yang H, Hui WZ, Rui F, et al. Epidemiology of COVID-19: A systematic review and meta-analysis of clinical characteristics, risk factors, and outcomes. J Med Virol. 2020; :1449-58. doi: 10.1002/ jmv.26424.

19. Siddiqi HK, Mehra MR. COVID-19 illness in native and immunosuppressed states: A clinical-therapeutic staging proposal. J Heart Lung Transplant. 2020;39:405-7.

20. Liu Y, Du X, Chen J, Jin Y, Peng L, Wang HHX, et al. Neutrophil-to-lymphocyte ratio as an independent risk factor for mortality in hospitalized patients with COVID-19. J Infect. 2020;81:e6-12.

21. Qin C, Zhou L, Hu Z, Zhang S, Yang S, Tao Y, et al. Dysregulation of Immune Response in Patients With Coronavirus 2019 (COVID-19) in Wuhan, China. Clin Infect Dis. 2020;71:762-8.

22. Qu J, Yuan H-Y, Huang Y, Qu Q, Ou-Yang Z-B, Li G-H, et al. Evaluation of neutrophil-lymphocyte ratio in predicting bloodstream infection. Biomark Med. 2019;13:1255-61.

23. Naess A, Nilssen SS, Mo R, Eide GE, Sjursen $\mathrm{H}$. Role of neutrophil to lymphocyte and monocyte to lymphocyte ratios in the diagnosis of bacterial infection in patients with fever. Infection. 2017;45:299-307.

24. Del Valle DM, Kim-Schulze S, Huang H-H, Beckmann ND, Nirenberg S, Wang B, et al. An inflammatory cytokine signature predicts COVID-19 severity and survival. Nat Med. 2020;26:1636-43. doi: 10.1038/s41591-0201051-9.

25. Chen T, Wu D, Chen H, Yan W, Yang D, Chen G, et al. Clinical characteristics of 113 deceased patients with coronavirus disease 2019: retrospective study. BMJ. 2020;m1091. doi: 10.1136/bmj.m1091.

26. Cao B, Wang Y, Wen D, Liu W, Wang J, Fan G, et al. A Trial of Lopinavir-Ritonavir in Adults Hospitalized with Severe Covid-19. N Engl J Med. 2020;382:1787-99.

27. WHO Solidarity Trial Consortium, Pan H, Peto R, Henao-Restrepo AM, Preziosi MP, Sathiyamoorthy V, et al. Repurposed Antiviral Drugs for Covid-19 - Interim WHO Solidarity Trial Results. N Engl J Med. 2021;384:497-511.

28. Hewitt J, Carter B, Vilches-Moraga A, Quinn TJ, Braude P, Verduri A, et al. The effect of frailty on survival in patients with COVID-19 (COPE): a multicentre, European, observational cohort study. Lancet Public Health. 2020;5:e444-51. 